uchwałę $\mathrm{w}$ sprawie nadania stopnia doktora habilitowanego nauk prawnych w zakresie prawa - prawa rzymskiego dr. Markowi Sobczykowi.

Podstawą ubiegania się o tytuł doktora habilitowanego był dorobek naukowy habilitanta wraz z rozprawą pt. Świadczenie w zamierzonym celu, który nie został osiqgnięty. Studium z prawa rzymskiego, opublikowaną w Toruniu w 2012 r.

Recenzentami w przewodzie byli: prof. dr hab. Marek Kuryłowicz z Uniwersytetu Marii Curie-Skłodowskiej w Lublinie i prof. dr hab. Andrzej Sokala z UMK w Toruniu (powołani przez Radę Wydziału WPiA UMK) oraz prof. dr hab. Jan Zabłocki z Uniwersytetu Kardynała Stefana Wyszyńskiego w Warszawie i dr hab. Piotr Niczyporuk, prof. Uniwersytetu w Białymstoku (powołani przez Centralną Komisję do Spraw Stopni i Tytułów). Habilitant wygłosił wykład pt. Przestęsstwo korupcji wyborczej w starożytnym Rzymie. Rada Wydziału Prawa i Administracji Uniwersytetu Mikołaja Kopernika jednogłośną uchwała nadała dr. Markowi Sobczykowi stopień naukowy doktora habilitowanego w zakresie prawa.

EWA GAJDA (Toruń)

\title{
OBRONY ROZPRAW DOKTORSKICH
}

Dnia 29 maja 2013 r. odbyła się na Wydziale Prawa i Administracji Uniwersytetu Marii Curie-Skłodowskiej w Lublinie obrona rozprawy doktorskiej mgr. Andrzeja Chmiela pt. „Zeznania świadków i ich wartość dowodowa w rzymskim procesie karnym". Promotorem w przewodzie doktorskim był dr hab. Krzysztof Amielańczyk, prof. nadzw. UMCS, zaś recenzentami: prof. zw. dr hab. Marek Kuryłowicz (UMCS) oraz dr hab. Renata Świrgoń-Skok, prof. nadzw. UR.

Obrona doktoratu odbyła się przed Komisją powołaną przez Radę Wydziału Prawa i Administracji UMCS. Po wysłuchaniu autoreferatu i uwag recenzentów miała miejsce dyskusja.

Dnia 19 czerwca 2013 r. Rada Wydziału Prawa i Administracji UMCS w Lublinie w tajnym głosowaniu postanowiła nadać mgr. Andrzejowi Chmielowi stopień naukowy doktora nauk prawnych w zakresie prawa.

Dnia 17 czerwca 2013 r. na Wydziale Prawa, Administracji i Ekonomii Uniwersytetu Wrocławskiego odbyła się publiczna obrona rozprawy doktorskiej mgr Barbary Pawełko-Czajki na podstawie pracy pt. Koncepcje polityczno-prawne wileńskich krajowców do 1945. Promotorem rozprawy doktorskiej był dr hab. prof. UWr Maciej Marszał. Recenzentami byli prof. dr hab. Arkady Rzegocki z Uniwersytetu Jagiellońskiego oraz prof. dr hab. Marek Maciejewski z Uniwersytetu Wrocławskiego.

W dniu 10 grudnia 2012 r. odbyła się na Wydziale Prawa i Administracji Uniwersytetu Gdańskiego publiczna obrona pracy doktorskiej mgr. Mikołaja Tarkowskiego. 
Podstawą przewodu była rozprawa zatytułowana Adwokatura wileńska 1918-1939. Promotorem w przewodzie doktorskim był prof. zw. dr hab. Dariusz Szpoper, recenzentami zaś - prof. dr hab. Zbigniew Naworski z Uniwersytetu Mikołaja Kopernika w Toruniu oraz prof. dr hab. Andrzej Wrzyszcz z Uniwersytetu Marii Curie-Skłodowskiej w Lublinie.

Komisja Rady Wydziału Prawa i Administracji przyjęła obronę rozprawy doktorskiej, a następnie Rada Wydziału podjęła jednomyślnie uchwałę o nadaniu stopnia doktora nauk prawnych mgr. Mikołajowi Tarkowskiemu.

SEBASTIAN STANKIEWICZ (Lublin)

TOMASZ CHLOPECKI (Wrocław)

JACEK WAŁDOCH (Gdańsk) 